ELORE (ISSN 1456-3010), vol. $16-1 / 2009$.

Julkaisija: Suomen Kansantietouden Tutkijain Seura ry.

[http://www.elore.fi/arkisto/1_09/kirjat_mahlamaki1_01_09.pdf]

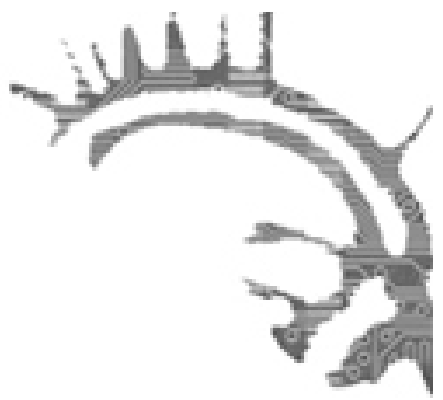

\title{
KIRJA-ARVIO:
}

\section{ÄÄNIÄ ÄÄNIEN TAKAA}

Outi Fingerroos \& Tuulikeki Kurki (toim.) 2008: Ä̈̈niä arkistosta. Haastattelut ja tulkinta. Suomalaisen Kirjallisunden Seuran Toimituksia 1194. Helsinki: SKS. 298 sivua.

\section{Tiina Mahlamäki}

Suomalaiset perinne- ja kielitieteelliset äänitearkistot kätkevät kokoelmiinsa kymmeniä tuhansia tunteja haastatteluaineistoja, mutta myös muunlaista ääntä, kuten musiikkia, erilaisia tilaisuuksia, seminaareja tai vaikkapa uskonnollisia seuroja. Arkistoitu äänimaailma on mittaamattoman rikas. Suomalaiset ääniteaineistot jakautuvat hyvin moniin eri arkistoihin. Julkaistu ääniaineisto on tallennettu Yleisradion äänitearkistoon sekä Kansalliskirjaston alaisuudessa toimivaan kansalliseen äänitearkistoon. Ei-julkaistu ääniteaineisto on levällään erilaisissa arkistoissa ja aineistojen säilytys, kunto ja tutkimuskäyttö ovat hyvin kirjavia. Opetusministeriön rahoittama Tieteellisten äänitearkistojen digitointi ja tiedonhallinta -hanke kokosi 2000-luvun alussa yhteen neljä tieteellistä arkistolaitosta: Suomen kielen nauhoitearkiston, Suomalaisen Kirjallisuuden Seuran kansanrunous- ja kirjallisuusarkistot, Tampereen yliopiston musiikintutkimuksen laitoksen sekä Suomen Jazz \& Pop Arkiston. Hankkeessa kartoitettiin olemassa olevia arkistojen äänitekokoelmia sekä niiden kuntoa, koska haluttiin pelastaa digitoimalla tuo korvaamaton äänimassa, jonka arkistointi perustui vain arkistojen omaan aktiivisuuteen ja innostuneisuuteen. Myös Suomen ensimmäiset ääniaineistojen digitointiprojektit lähtivät tuosta huolesta, sekä innostuneisuudesta digitoinnin avulla avautuviin uusiin mahdollisuuksiin.

\section{METAFORISET ÄÄNET}

On tärkeää, että arkistojen ääniaineistot saavat oman, juuri niiden erityiskysymyksiin - metodologisiin, metodisiin, arkistoteoreettisiin sekä digitoinnin ja digitaalisten 


\section{Ä̈̈NIÄ ÄÄNIEN TAKAA}

aineistojen problematiikkaan - pureutuvan teoksen. Tartuin siis suurin odotuksin artikkelikokoelmaan, joka oli nimetty otsikolla Ä̈̈niä arkistosta. Alaotsikko on rajattu koskemaan haastatteluja ja niiden tulkintaa. Ääni käsitteenä määritellään teoksessa hyvin väljästi, eikä otsikon 'arkisto' tule esiin monessakaan tekstissä. Itse asiassa vain neljäsosa teoksesta käsittelee arkistoituja aineistoja, suurin osa artikkeleissa käytetyistä haastatteluaineistoista ilmoitetaan olevan kirjoittajan tai tutkijaryhmän hallussa. Toivottavasti nekin haastattelut aikanaan päätyvät arkistoon. Teoksen pääpaino on siis selkeästi sen ala- eikä pääotsikossa. Siinä ei pohdita kysymyksiä äänitteistä arkistoissa, äänitteen asemasta arkistoaineistona tai ääniaineistojen digitointia muutoin kuin viimeisen, arkistonjohtaja Lauri Harvilahden katsauksen osalta.

Takakannessaan teos kertoo tarkastelevansa "etnografisten haastatteluaineistojen muodostamiseen, käyttöön ja tulkintaan liittyviä kysymyksiä", joten voimme odottaa metodisesti painottunutta teosta, joka soveltunee perinteentutkijoiden, eritoten folkloristien oppikirjaksi. Erittäin tärkeää on, että teoksen läpäisevänä juonteena kulkevat tutkimuseettiset kysymykset, sillä tutkimusetiikka ei ole mitenkään erillinen ja irrallinen alue, vaan sitä pitäisi käsitellä kaikessa ihmistieteellisessä tutkimuksessa, itsestään selvänä, koko tutkimusprosessin läpi jatkuvana lankana. Artikkelikokoelmassa eettiset kysymykset painottuvat yhtäältä tutkijan ja tutkittavan väliseen vuorovaikutukselliseen suhteeseen ja toisaalta tutkijan aineistostaan tekemiin tulkintoihin. Molempiin liittyy keskeisesti vallan problematiikka. Artikkelit lähestyvät johdantoartikkelin osoittamalla tavalla äänen käsitettä metaforisesti, jolloin tutkijan tehtäväksi useinkin nousee "äänen antaminen" tutkittavilleen, vaiettujen ja hiljennettyjen äänien esiin nostaminen.

\section{VAIENNETTUJEN ÄÄNET}

Artikkelikokoelma jakautuu alku- ja loppukehysten sisässä neljään osioon. Ensimmäisen, haastatteluja ja ääniä käsittelevän osion kentät haarautuvat moniaalle. Helena Saarikoski kuvaa artikkelissaan erilaisia kenttiään, keskittyen kuvaamaan omaa tutkimus- ja tutkijuushistoriaansa, jonka kehyksenä on ollut feministinen ote, marginaalien kuunteleminen ja tutkittavien voimaannuttaminen. Karina Lukinin kenttä taas on kaukana, nenetsien parissa, jolloin haastateltavat poikkeavat haastattelijastaan niin iältään, kieleltään, elinolosuhteiltaan, koulutukseltaan, uskonnoltaan kuin kulttuuriltaankin. Ei ihme, että Lukin kuvaa artikkelissaan epäonnistuneita haastatteluja. Mutta niistäkin saa tietoa. Kun ottaa vakavasti ajatuksen tiedon osittaisuudesta, voi epäonnistuneelta tuntuneesta haastattelupuheesta saada irti monenmoista. Paikantumisen käsitteen riemastuttavin havainto on se, että jokaisesta paikasta näkee johonkin. Airi Markkasen artikkelin kenttä muodostuu romaneista, pääosin Suomessa, mutta romanitutkimusverkostojen myötä myös muualla Euroopassa. Markkanen on kotoutunut haasteelliselle kentälleen ja tullut hyväksytyksi siellä. Hän työskentelee erilaisissa ympäristöissä ja monin tavoin tuottaakseen positiivisia sävyjä romanipuheeseen ja tarjotakseen romaneille mahdollisuuden ilmaista omaa ääntään positiivisella tavalla. 


\section{KUVIEN ÄÄNET}

Äänien tavoittamiselle nimetyssä osiossa Kaisu Kortelainen kuvaa, miten haastateltaville esitettävien valokuvien avulla tuotetaan haastattelupuhetta ja muistitietoja monin, tutkijaa yllättävinkin tavoin. Hänelle äänet ovat aineistosta eri tavoin eri katsojille ja eri katsomistilanteissa välittyviä viestejä. Kuvat nostavat mielen pintaan muistikuvia, mutta myös ääni-, haju- ja makumuistoja tai muistoja ruumiillisesta työstä. Kuvien katsominen voi tuoda tutkijan mieleen myös kuvaajan äänen, hänen kertomuksensa. Kortelainen nostaa esiin myös kuvien avulla tuotetun haastattelupuheen arkistointiprosessin haasteellisuuden.

Metodisiin kysymyksiin keskittyy myös Johanna Uotisen artikkeli, jossa hän vertailee haastatteluaineiston analyysin menetelmiä, Atlas/ti-tietokoneohjelmaa sekä etnografista laadullista analyysiä jälkimmäisen eduksi. Artikkeli antaa yksityiskohtaisen mutta harvinaislaatuisen kuvauksen tulkinnan epäonnistumisesta tai ainakin puutteellisuudesta hankalakäyttöisellä ja jäykällä tietokoneohjelmalla. Tutkija on laadullisen tutkimuksen keskeinen työkalu, jolloin tutkiminen ajattelemalla ja kirjoittaminen tietämisen tapana osoittautuvat parhaimmiksi analyysin menetelmiksi. Artikkeli poikkeaa kokoelman muista teksteistä siinä, että se kantaa ilman itse tutkimusaineiston kuvausta. Se osoittaa, että metodologisista kysymyksistä voi kirjoittaa elävästi ja kiinnostavasti ilman tietyn aineiston ja tutkimuskohteen esittelyä. Joissain artikkeleissa tutkimusaineiston tai -kentän esittely vie liikaakin tilaa metodologisten kysymysten jäädessä vähemmälle.

\section{Neuvotellut ÄÄNET}

Kolmas osio, Äänet prosessissa, alkaa Elina Makkosen kuvauksella Joensuun yliopiston suullisen muistin projektista, jossa kerättiin muistitietoa yliopiston kolmen vuosikymmenen mittaisen toiminnan ajalta. Joensuussa päädyttiin kokoamaan suullista muistitietoa ja haastateltiin korkeakoulun perustamisvaiheessa mukana olleita, emeritusprofessoreita ja pitkän linjan opiskelijoita. Erinomaista Joensuun yliopiston suullista muistia tavoitelleessa projektissa näyttää olleen muun muassa se, että on haastateltu myös ruokaloiden, kirjastojen, hallinnon ja puhelinkeskuksen henkilökuntaa. Yliopistolaisia hekin, vaikka heidät usein unohdetaan.

Makkonen kuvaa konkreettisesti aineiston muodostumisprosessia, unohtamatta arkistointiprosessin kuvausta ja aineiston kuvailua. Instituution muistia kartoitettaessa toisinaan muistot ovat hyvin erilaisia kuin virallisissa historiankirjoituksissa, toisinaan taas instituutio puhuu haastateltavien lävitse. Sari Tuuva-Hongiston artikkelissa, jonka aineisto koostuu yhden tietoyhteiskuntaprojektiin osallistuneen aktiivihenkilön useasta haastattelusta, projekti tuntuu puolestaan puhuvan haastateltavan lävitse. Keskeiseksi metodiseksi kysymykseksi nousee, kenen äänellä haastateltava puhuu, omalla yksityisellä vai hankkeen virallisella äänellä? 


\section{ÄÄNIÄ ÄN̈NIEN TAKAA}

\section{TUNTEIDEN ÄÄNET}

Artikkelikokoelman kolmannessa osiossa Pälvi Rantalan käsittelemän Kalkkimaan papin omaa ääntä ei ole käytettävissä, vaan tulkinta perustuu eri kertojien ja muiden aineistojen hänestä antamaan, osin ristiriitaiseenkin kuvaan. Arkistonäkökulmasta mielenkiintoisena yksityiskohtana nousee esiin haastateltavan rauhoittamiseksi ja puheen jatkumisen turvaamiseksi tarkoitettu lupaus siitä, että haastattelu "menee vain Helsingin arkistoon". Tämä on aiemmin haastatteluissa paljon käytetty, mutta nykykäsityksen ja voimassaolevan lainsäädännön näkökulmasta ristiriitainen ja jopa valheellinen lupaus. Se sisältää implisiittisesti ajatuksen siitä, että aineistot menevät jonnekin kaukaiseen arkistoon, jossa kukaan haastateltavan tuntema henkilö ei pääse niihin käsiksi ja jossa ne vain keräävät pölyä ihmiskäden koskematta, ihmiskorvan kuulematta. Näinhän ei asia ole, vaan aineistot kerätään nimenomaan tutkimuskäyttöön, tutkijoiden kuultaviksi ja tulkittaviksi. Rantala itse tekee artikkelissaan eettisesti kestävää työtä avatessaan hyvällä ja yksityiskohtaisella tavalla omaa lukemisen tapaansa, omaa tutkijan paikkaansa ja omien tulkintojensa luotettavuutta. Hän tuo esiin myös turhautumisensa haastateltavien "vääristä", yksipuolisista ja aikaan sidotuista näkemyksistä. Kiusaantuminen ja ärsyyntyminen nauhoja kuunnellessa osoittavat siten paikkoja, joihin tutkijan on pysähdyttävä ja tarkistettava ennakkokäsityksiään ja tulkintojaan.

Kati Heinosen artikkeli nostaa esiin kaksi tärkeää ja toisiinsa kytkeytynyttä näkökulmaa ääniaineistojen tulkinnassa: tunteet ja kielenulkoisen viestinnän. Hän kuuntelee herkällä korvalla siirtokarjalaisen perinteentaitaja Elmi Tšokkisen kehtolaulua. Laulu valikoituu tai täsmentyy tarkan analyysin kohteeksi tunteen perusteella: niin nauhalle laulaja kuin nauhaa kuunteleva tutkija itkevät "Aa aa allista" -kehtolaulun lopulla. Myös kyseistä laulua koskaan kuulematon arvostelija liikuttui ja mieleen nousivat omat muistot arkistotyöstä, miten vahvat itkuvirret nostattivat kyyneleet nauhoja kopioivan silmiin, vaikka en laulujen sanoista mitään ymmärtänytkään. Muun muassa itkuvirsiä tutkinut folkloristi Aili Nenola on nostanut esiin itkun merkityksen tutkimuksen kohteena mutta myös tutkijan oikeutena: "Itke, mutta tutki", hän kehottaa. Näin tekee Heinonen analysoidessaan paitsi itse kehtolaulua myös laulun nauhoitustilanteen kontekstia, jossa nuori kansanrunouden opiskelija Juha Pentikäinen intensiivisesti ja ilmeisen herkästi reagoi tilanteeseen häntä yli puoli vuosisataa vanhemman perinteentaitajan kanssa. 1960-luvun metodioppaat määräsivät häivyttämään haastattelijan reaktiot tallenteista, mutta Heinosen tarkka hiljaisuuksien kuuntelu tuo esiin paitsi laulajan myös äänittäjän ja haastattelijan liikutuksen.

\section{KIRJOITETUT ÄÄNET}

Nostan artikkelikokoelmasta erillisenä aiheena vielä esiin merkittävän, ääniaineistoihin liittyvän metodisen kysymyksen, johon useissa artikkeleissa eri tavoin viitataan. Tutkimuksen kuluessa tutkittavat äänet on muokattava kirjalliseen muotoon. Litterointi on työläs, hidas ja joskus hyvin turhauttava vaihe. Litteroitavia aineistoja on monenlaisia ja 
litterointitavat vaihtelevat tutkimuskysymyksestä ja analyysin tavasta riippuen. Lukuisat tutkijat ovat myös kuvanneet litterointivaihetta aikana, jolloin aineistoon uppoutuu, tulee sen kanssa sinuiksi. Hyvälaatuinen äänitys luo kuuntelijalleen erityislaatuisen läsnäolon tunteen ja palauttaa haastatteluhetken tilaan ja tilanteeseen ja sen intensiiviseen tunnelmaan. Saarikoski nostaa esiin, miten muunnettaessa puhetta kirjalliseen muotoon ollaan myös eettisten kysymysten äärellä. Tutkijan on huolellisesti pohdittava valtaansa tutkittavan ilmaisuun. Saarikoski itse on varannut haastateltavilleen mahdollisuuden stilisoida omien puheidensa kirjallista esitystä, myös tutkija itse voi muuntaa puhekielisyydet lähemmäs omaa, kirjallista ilmaisuaan.

Tanssintutkijana Saarikoski on kehittänyt tapoja, joilla liikettä tai äänenpainoja voidaan kuvata sanoin. Myös Kortelainen pohtii kineettisyyden tekstualisoimista. Hän huolehtii valokuviin perustuvien haastattelujensa arkistoinnissa siitä, että myös niiden jatkokäyttö olisi mahdollista. Tämä tarkoittaa sitä, että on arkistoitava myös itse kuvat, jotta haastatteluja kuunteleva pystyy tavoittamaan puheen merkitykset, sen mistä milloinkin puhutaan. Mutta sekään ei riitä. Olisi pystyttävä tekstualisoimaan myös haastateltavien liikkeet, miten he osoittavat katsomastaan kuvasta jotain tiettyä kohtaa. Kortelainen oppi haastattelujen edetessä antamaan äänen näille haastateltavien liikkeille: "Te olette asunut tuossa keskimmäisessä talossa" (s. 127). Kielenulkoisia kysymyksiä pohtii myös Heinonen pyrkiessään tuomaan tulkintaansa ja tekstualisoimaan haastateltavan äänestä kaikuvia tunteita, epäröintiä, surua, väsymystä ja itkua. Tulkinta on aina epävarmaa ja osittaista, mutta tekemiensä valintojen oikeellisuutta Heinonen pyrkii varmistamaan toisten kuuntelijoiden tulkinnoilla sekä paikalla olleelta haastattelijalta, joskin 40 vuotta haastattelutilannetta myöhemmin.

\section{OPPIHISTORIAN ÄÄNI}

Kansanrunousarkiston johtajan Lauri Harvilahden oppihistoriallinen, metodinen ja metodologinen katsaus kohdentuu kansanperinteen ääniaineistojen keruuseen, tutkimukseen ja tulkintoihin. Se antaakin osviittaa siitä, millaisia kysymyksiä arkistoidun äänen problematiikkaan keskittyvässä teoksessa tulisi myös tarkastella. Äänimateriaalin tallentaminen on ollut Suomen oloissa ylipäätään mahdollista vasta reilut sata vuotta. Koulu- ja kuppikuntien ja tieteenalojen asettamien kehysten lisäksi teknisellä kehityksellä on ollut suuri rooli ääniaineistojen tuottamisessa. Metodologisesti merkittävin tapahtuma suomalaisessa kenttätutkimuksessa on ollut vuoden 1965 Vöyrin pohjoismainen kenttätutkimusseminaari. Samoihin aikoihin yleistyivät kannettavat nauhurit ja avokelanauhoihinkin alkoi löytyä rahaa. Lauri Hongon näkemys oli, että nimenomaan autenttiset ääniaineistot ovat tutkimuksellisesti parhaita. Niinpä hänen perustamansa Turun yliopiston folkloristiikan ja uskontotieteen TKU-kokoelma on nimenomaan äänitearkisto, joskin siellä on myös kirjallista ja kuvallista arkistoaineistoa, muun muassa Hongon työryhmineen keräämä Siri-eeposaineisto.

Filosofian tohtori Tiina Mahlamäki on uskontotieteen tutkija ja arkistovastaava Turun yliopiston kulttuurien tutkimuksen laitoksella. 